\title{
The Economics of Corruption and the Corruption of Economics: An Institutionalist Perspective
}

Geoffrey M. Hodgson and Shuxia Jang The authors are from the Business School, University of Hertfordshire, UK and the College of Economics, Xiamen University, China. They are very grateful to Jitendralal Borkakoti, Michael Dietrich, Jane Hardy, David Reisman and others for helpful comments on earlier versions of this paper.

Corruption is now a popular topic in the social sciences. This expansion of interest is evident in economics and elsewhere, where a large number of articles on this theme have been published in leading journals. Some organizations publish indicative data on corruption. For example, Transparency International publishes a widely cited "Corruption Perceptions Index" for most countries, and these data are frequently used in statistical analyses of economic performance.

Transparency International data for 2005 suggest that corruption is "rampant" in more than 70 countries. These include populous and fast-growing economies such as China and India, which account for a large and rapidly increasing share of the global economy. Recent empirical studies indicate that corruption has a negative effect on economic performance (Shleifer and Vishny 1993; Mauro 1995; Aidt 2003; Jain 2001; Pelligrini and Gerlagh 2004). The World Bank (1997) has identified corruption as "the single greatest obstacle to economic and social development."

However, much less attention so far, has been devoted to the concept of corruption, its meaning and its definition. This means much more than the lack of tidy terminology. As Arvind Jain $(2001,73)$ observes: "While it may appear to be a semantic issue, how corruption is defined actually ends up determining what gets modelled and measured." Similarly, Toke Aidt (2003, F623) remarks that "the definition of the concept determines what gets modelled and what empiricists look for in the data." It is argued here that this conceptual lacuna in the literature has led some authors - particularly economists - to adopt a narrow and inadequate definition of corruption that has led to skewed empirical measures and biased policy recommendations.

It is shown below that prevailing definitions of corruption unwarrantedly and misleadingly confine the phenomenon to the public sector, despite the fact that

private sector corruption is often acknowledged. In addition, the rare but real phenomenon of "noble cause corruption" suggests that corruption is not strictly and universally for private gain, despite selfish motives often being involved. Another distorting factor that pervades the literature on corruption is the utilitarian reduction of morality to matters of utility or satisfaction. Consequently, the moral dimension of corruption has been dissolved into the hedonic calculus of individual gain or loss. Ideological and theoretical biases, prevalent in mainstream economics and elsewhere, have corrupted the concept of corruption.

With the exception of the rhetorical allusion to the "corruption of economics," this article is concerned with organizational corruption, rather than corruption in a broader sense, such as the corruption of language or a single individual. The following section criticizes the idea that organizational corruption is confined to the public sector only. A much shorter subsequent section briefly establishes that corruption need not always be for private gain. Another section criticizes utilitarian treatments of corruption and establishes its immoral character, leading to a specific definition of organizational corruption involving the violation of established, normative rules. From this perspective it is argued in the penultimate section that organizational corruption incurs social costs that cannot fully be internalized.

\section{Is Corruption Confined to the Public Sector?}

The root of the word "corruption" is in the Latin adjective corruptus, meaning spoiled, broken or destroyed. According to the Concise Oxford English Dictionary, a meaning of to corrupt in the social context is to bribe, and corruption amounts to "moral deterioration." Neither of these definitions nor the Latin etymology of the word, confines the notion of corruption to the public sector. Accordingly, corruption can occur in the private sphere as well.

Prominent international organizations adopt a similarly inclusive definition of corruption. The United Nations Office on Drugs and Crime emphasizes that corruption "can occur in both the public and private domains." Its Global Programme Against Corruption (GPAC) defines corruption as the "abuse of power for private gain" and 
includes thereby both the public and private sector. ${ }^{4}$ Similarly, the World Bank does not regard corruption as confined to the public sector and has identified several cases of corruption among private corporations. For Transparency International, corruption is operationally defined as "the misuse of entrusted power for private gain." This too covers individuals in both the private and public sectors.

Among economists, however, a different consensus prevails. In his overview article, Jain (2001, 73, emphasis added) declares "there is a consensus that corruption refers to acts in which the power of public office is used for personal gain in a manner that contravenes the rules of the game." In another major survey article in a journal of economics, Aidt (2003, F623, emphasis added) writes: "Corruption is an act in which the power of public office is used for personal gain in a manner that contravenes the rules of the game."

The survey articles by Jain (2001) and Aidt (2003) accurately report and endorse the tendency of most economists to confine their definition of corruption to the public sphere. For example, in a widely cited article simply titled “Corruption," Andrei Shleifer and Robert Vishny $(1993,599)$ confine their attention to government corruption only, defining it as "the sale by government officials of government property for personal gain." The influential study of the negative effects of corruption on economic growth by Paolo Mauro (1995) has the unqualified word "corruption" in its title but in the text mentions government corruption only. Likewise, Daron Acemoglu and Thierry Verdier (2000) also have the unqualified word "corruption" in their title but in their analysis they confine themselves entirely to the corruption of government officials. Like many others, Daniel Treisman (2000, 399) defines corruption as "the misuse of public office for private gain." A. Mitchell Polinsky and Steven Shavell (2001) confine their study to corruption in law enforcement. By definition or default, many economists confine their attention to corruption in the public sector. There are exceptions, and there is some discussion of private sector corruption in the literature, but a pronounced and questionable bias remains.

A search for the phrase "corporate corruption" in the text of all the journals of economics in the large JSTOR (The Scholarly Journal Archive) electronic database of leading journals found only three articles in which the phrase was used, and none later than 1977. By contrast, a search in the same journals in the same database found 25 articles using the phrase "government corruption" and 9 using "public corruption." The search was then widened to all items on the ISI Web of Knowledge (http://isiwebofknowledge.com/), in all available disciplines. In the accessible text of

35.9 million items, 13 mentioned "corporate corruption," 22 mentioned "government corruption" and 8 mentioned "public corruption." This shows that the frequency of the phrase "corporate corruption," relative to the phrases concerning corruption in the public sector, is much less when the search is narrowed to leading journals in economics. Mainstream economists are much more likely to consider public sector rather than corporate corruption.

However, this dubious bias is not confined to journals in economics. An early and influential article by the political scientist Joseph Nye $(1967,419)$ defined corruption as the deviation from the formal duties of a public role for private gain. Subsequently, in one of the few articles devoted entirely to the definition of corruption in the literature, John Gardiner $(1993,112)$ proclaims approvingly without much reflection: "All probably would agree with Nye's emphasis on public roles." Similarly, Daniel Kaufmann $(1997,114)$ is also among the many social scientists who define corruption as "the misuse of public office for private gain." He is followed by Wayne Sandholtz and William Koetzle $(2000,31)$ and numerous others. Mark Warren $(2004,328-9)$ asks the question "what does corruption mean in a democracy?" and then immediately confines himself to political corruption and "the misuse of public office for private gain.” The analysis in Susan Rose-Ackerman's $(1999,9)$ important and influential book is deliberately confined to government corruption, which is defined as payments "illegally made to public agents with the goal of obtaining a benefit or avoiding a cost."

Two logical bases of this questionable bias are possible. One is to define corruption in terms that confine it explicitly to the public sector. Another is to admit a broader definition, but for some reason to bias research toward corruption in the public sphere. Examples of both stances can be found in the literature. We also need to explain what motivates either form of this bias.

There is, of course, a huge and rapidly growing literature on business ethics, and moral issues are salient in the corporate governance literature and elsewhere. Often, other ethically loaded words are used instead of the term "corruption" in these literatures. Partly this is because of a concern with the ethical behavior of a corporation as such, rather than corruption within organizations. Nevertheless, terms such as "corporate corruption" and "business corruption" are in widespread use in popular and even legislative discourse.

In sum, much of the literature on corruption in the social sciences has restricted itself to the public sector. This is objectionable, for several reasons. First, it ignores the reality of corruption in the private sphere. One need only 
mention the word Enron. There are well known instances of corruption in trade unions, including the U.S. Teamsters Union (Friedman and Schwarz 1989). Corruption has also been found in sports, including the bribing of players or challengers to "throw" contests. In 1997, the Organization for Economic Cooperation and Development (OECD) member states adopted a convention making business bribery abroad a criminal offense in the home country of the bribing firm. The opening years of the twenty-first century were marked by major cases of corporate fraud, involving U.S.-based companies such as Enron, WorldCom, Adelphia and Parmalat. Alarm about corporate fraud and corrupt accounting practices fuelled political pressure in the U.S. Congress. In response, President George W. Bush signed a "Corporate Corruption Bill" in July 2002, thus endorsing the notion that corruption is more than a purely governmental phenomenon.

Second, there are several ways of defining the boundary between the public and private sectors, leading to classificatory problems if corruption is definitionally restricted to the public sphere. Consider a private corporation of which the state owns 51 percent of its share capital. Is it part of the public or the private sector? Does corruption within it magically cease if this state ownership drops from 51 to 49 percent? Some organizations - including nearly all British universities and the newly devised "foundation hospitals" in England - are formally private, but largely dependent on state funding and consequently come to some degree under state control. Are these in the public or the private sector? In response, one can refine the definition of the public or private sector, but that is beyond the point. We should be interested in the reality of corruption, whether or not these institutions are formally defined as public or private.

Third, institutions that in some nations are private can be public elsewhere. In some countries, postal services, railways and universities are entirely run by the state. University professors and other functionaries in these sectors are essentially civil servants or state officials. Yet elsewhere, one can find instances where these services are privatized. An act of bribery involving an official within the French university, postal or railway systems would be corruption by most definitions. But would it cease to be so if it occurred in the private equivalents of these institutions elsewhere, in say the United States? An affirmative answer would be absurd. Furthermore, France might have more corruption than another country with similar levels of dishonesty, simply because the public sector is larger. Once again, restricting the definition of corruption to the public sector leads to severe anomalies.

Fourth, corruption is typically contagious and does not respect sectoral boundaries. Corruption involves duplicity and reduces levels of morality and trust. Once it takes root, it tempts others with its pecuniary gains and reduces incentives to conform to the rules. As levels of morality and trust are lowered, it becomes more difficult to resist corrupt practices. Virulent corruption can spread quite easily from the private to the public sector, or vice versa. Corruption involves negative externalities that traverse sectoral boundaries, by undermining legal and moral norms and facilitating further corrupt acts. Consequently, empirical studies of the levels of corruption should be comprehensive and unconfined to the public sphere.

Given the absurdity of restricting the study and definition of corruption to the public sector, one may ask why so many social scientists define it in these limited terms? Political scientists may plead that their very role is to study political institutions, but this does not warrant the confinement of the definition to this terrain.

Economists do not even have this excuse. One possible reason for their biased concern with public sector corruption is the widespread influence of individualistic and libertarian ideology. A primary target in this ideology is the abuse of power by politicians. The misuse of power by directors of large corporations does not raise the same level of concern among leading individualistic and libertarian thinkers such as Milton Friedman and Friedrich Hayek. According to this stream of thought, most voluntary contracts between consenting adults are moral and legitimate, as long as they do not harm others. Ignoring the negative externalities of corruption, it has been further argued from a libertarian perspective that bribery and other forms of corruption in the private sphere have potential benefits, and are expressions of entrepreneurial activity. By contrast, corruption in the public sector involves the misuse of powers within questionable state institutions. In sum, the bias toward public sector corruption in the literature partly reflects an ideological notion that the private sector is the zone of largely unconstrained individual liberty, whereas the state represents its antithesis and must be subject to rigorous scrutiny, confinement and restraint.

From this individualistic and libertarian perspective the temptation is to see the solution to the problem of corruption as the reduction of the size of the state, particularly if corruption is defined as essentially a state phenomenon. As an extreme case, Nobel Laureate Gary Becker is quoted in Business Week as declaring: "if we abolish the state, we abolish corruption" (Tanzi 2000, 112). Of course, this would be true if corruption was definitionally confined to state institutions, but it is not particularly helpful or feasible. The alternative statement "if we diminish the state, we diminish corruption" would sustain the view that extensions of privatization and market competition are 
generally effective cures for a corrupt polity. Is such a proposition tenable?

Evidence of enduring corruption in the transitional economies challenges this stance. Corruption was endemic in the Soviet-type regimes in China and Eastern Europe. However, it has persisted since 1989, as the economic powers of the state have diminished and markets and private ownership play a much more important role. ${ }^{10}$ In Russia in particular there is evidence that corruption has increased dramatically in the 1990s despite extensive privatization (Levin and Satarov 1991). As Rose-Ackerman (1999) elaborates, the outcome of privatization in any country may reduce some types of state corruption by diminishing the economic role of the state, but also, as the evidence shows, the process of privatization can enhance some particular opportunities for corruption by state officials. Overall, the evidence does not show that levels of corruption in general, or even public sector corruption in particular, are closely related to the size of the state. Crucially, some of the least corrupt countries according to published indicators, such as Denmark, Finland, Holland, Norway and Sweden, have the largest levels of public spending as shares of GDP.

As Jonathan Hopkins $(2002,585)$ points out, the anti-corruption strategies advocated by mainstream economists largely consist "of two main planks of reform: reforming the state administration to minimize corrupt incentives, and reducing the role of the state in economic life in order to leave as much economic activity as possible in the hands of the market." The role and extent of corruption in the private sector is largely neglected.

In contrast, an institutionalist perspective has provided an alternative view of the state and law, with important implications for the analysis of corruption. This alternative is found within the literature of the German historical school and original institutional economics in America. According to this line of thought, individual property is not mere individual possession; it involves socially acknowledged and enforced rights (Commons 1924; Samuels 1989; Hodgson 2003). Individual property is not simply a relation between an individual and an object. It requires some kind of customary and legal apparatus of recognition, adjudication and enforcement. Similar considerations apply to the market: rather than the mere ether of individual interaction, markets are social institutions. Most of them are structured in part by statutory rules (Lowry 1976; Hodgson 1988; Fligstein 2001; McMillan 2002; Chang 2002).

Many important legal rules, enforcements and structures cannot emerge spontaneously through individual interactions. They require additional third party enforcement by the state or another strong institution." This means that many key institutions and legal relations, arguably including property and markets, exist as a result of a combination of spontaneous and statutory mechanisms. Institutions are generally and inevitably intertwined, and often provide essential mutual support for one another. The existence of one institution has to be considered in relation to the others that help to support and sustain it, including state institutions where relevant. Public and private spheres are intertwined and inseparable.

These institutionalist propositions concerning the necessary role of the state, and the interpenetration of (public and private) institutions in a market economy, undermine definitions of corruption that limit it to the public sector. Corruption is an institutional phenomenon, affecting both private and public spheres.

\section{Is Corruption Always and Necessarily for Private Gain?}

It is argued above that corruption should not be restricted definitionally to the public sphere. This brief section criticizes the other half of the commonplace definition of corruption as the "misuse of public office for private gain." The idea that corruption always involves "private gain" is almost as problematic as the first part of this definition.

Of course, if we start from the utilitarian idea that all individual actions are performed to increase individual pleasure or utility, then all actions - including corrupt deeds - involve individual or private "gains" in that sense. All acts are "explained" in terms of individual utility maximization. However, from this unfalsifiable utilitarian perspective, the second half of the commonplace definition is redundant, because all acts are seen as motivated by such gains, and actions to the contrary are denied.

By contrast, one may define the phrase "for private gain" more narrowly, and confine it to cases where the persons concerned obtain some kind of tangible personal reward, with the receipt of money, status, goods or services. However, although this may cover the majority of cases of corruption in the real world, it excludes some important cases where individuals act corruptly for moral ends. This is sometimes called "noble cause corruption" (Miller 2005; Miller, Roberts and Spence 2005).

A good example is the bribing for higher motives of officials under a totalitarian or repressive regime. For 
instance, Oskar Schindler bribed Nazi officials to prevent over a thousand Jews from being sent to the concentration camps, as depicted in the movie Schindler's List (and the book Schindler's Ark from which it is derived).

Many real world cases involve a mixture of motives. Consider two police officers, believing that a criminal is guilty (perhaps also having clear evidence of guilt that cannot be used in court) fabricate evidence to secure a conviction. Although this may also improve the police officers' chances for promotion and thereby in part be motivated by "private gain," the moral motive of convicting a dangerous criminal may also be highly significant.

Although these actions are not necessarily for material gain, they remain corrupt because they break specific rules and undermine their character and moral justification. On the supreme scales of moral calculus, the immoral act of corruption may be outweighed by the moral outcomes of the noble cause, but corruption remains corruption nevertheless.

It may be objected that motives of personal gain are so commonly behind corruption that this term can be retained in the definition. This argument confuses definition with description. The definition of a mammal does not necessarily include commonplace mammalian features such as lungs and body hair. The role of a definition is to get to the essential distinguishing characteristics, or to "carve reality at the joints" as Plato put it. Overall, we may conclude that the phrase "for private gain" plays no vital role in the definition of corruption, even though private gain is often important.

Both components of the commonplace "misuse of public office for private gain" definition have been undermined. An adequate alternative definition of organizational corruption is required.

\section{Defining Organizational Corruption: Rules, Utilitarianism and Morality}

It has been noted above that the etymology of the word "corruption" suggests a broad and general meaning. What concerns us here is the nature of corruption within (public and private) organizations. Two propositions that are relevant to the conceptual analysis of corruption are thematic to the older tradition of institutional economics, and the philosophy and psychology of pragmatism to which it relates.

The first proposition is that institutions are the stuff of social life. Institutions refer to systems of established and embedded social rules that structure social interactions (Hodgson 2006a). Organizations are particular kinds of institutions involving rules concerning membership and sovereignty, with examples including states and firms. ${ }^{12}$ In this context, the general emphasis on institutions reflects the concern with forms of corruption that corrode the institutional and social fabric. Because of their emphasis on institutions, institutional economists are more alert to rules and their infringement.

This first proposition also invokes a fundamental shift of ontological outlook, where social reality is regarded as constituted by structures made up of social rules (Ostrom 1986; Crawford and Ostrom 1995; Hodgson 1997; Potts 2000; Dopfer, Foster and Potts 2004). In turn, these rules are sustained by psychological habits (Veblen 1919; Ouellette and Wood 1998; Hodgson and Knudsen 2004). Habits themselves are conditional and rule-like. The role of habit is important in the context of organizational corruption, because it typically involves a sustained pattern of imitable corrupt actions that are driven by corrupt habits or dispositions.

The second proposition concerns the normative nature of social rules. The term rule is broadly understood as a socially transmitted and customary normative injunction or immanently normative disposition, that in circumstances A do B. The term socially transmitted means that the replication of such rules depends upon a developed social culture and some use of language. Such dispositions do not appear simply as a result of inherited genes or instincts.

The prevailing rule structure provides incentives and constraints for individual actions. Channeling behavior in this way, accordant habits are further developed and reinforced among the population. Habits are the constitutive material of institutions, providing them with enhanced durability, power and normative authority. In turn, by reproducing shared habits of thought, institutions create strong mechanisms of conformism and normative agreement. As Charles Sanders Peirce $(1878,294)$ declared, the "essence of belief is the establishment of habit." Accordingly, habit is not the negation of deliberation, but its necessary foundation. Reasons and beliefs are often the rationalizations of deep-seated feelings and emotions that spring from habits laid down by repeated behaviors (Kilpinen 2000; Wood, Quinn and Kashy 2002).

This interplay of behavior, habit, emotion and rationalization helps to explain the normative power of custom in human society. Hence "custom reconciles us to everything" - as Edmund Burke wrote in 1757 - and customary rules can acquire the force of moral authority. In turn, these moral norms help to further reinforce the 
institution in question.

Both propositions - that institutional rule-systems are the stuff of society, and social rules have a strong normative dimension - challenge the mainstream economics of the second half of the twentieth century. Ontologically, this type of economics focused on inputs and outputs in systems with maximizing agents where everything was connected with everything else. Instead, the institutionalist paradigm invoked here starts from structures of differentiated interconnectedness, involving interactions between rule-driven rather than maximizing agents (Potts 2000; Vanberg 2002).

Ethically, mainstream economics remains largely utilitarian: policy goals are measured in terms of individual utility or happiness. It further presupposes that the individual is the best judge of his or her welfare, and typically invokes the Pareto criterion to establish normative propositions. Ethical concerns become reducible to the maximization of utility by individuals. There are several varieties of utilitarianism and some emphasize rules and institutions. However, what they have in common is the idea that the ultimate moral goal is the maximization of happiness, satisfaction or utility. In contrast, the institutionalist approach invoked here joins with the many dissenters to utilitarianism to uphold that moral issues are not entirely reducible to utility maximization or individual happiness.

Unavoidably, the adherence to social rules involves the moral commitment to associated ethical values. Such issues are widely acknowledged in professions that have established ethical standards, including the medical profession. They are also important for the conduct of scientific research. The crucial point is that not only the manifest adherence to behavioral rules is required, but also the inner moral commitment to appropriate values is necessary. Such moral commitments or habits transcend the calculus of punishments or rewards. In such contexts, rational utilitarian calculations of gains and losses are widely regarded as insufficient for deciding behavior: "Citizens who refrain from treason merely because it is against the law are, by that fact, of questionable loyalty; parents who refrain from incest merely because of fear of community reaction are, by that fact, unfit for parenthood" (Hagstrom 1965, 20). Accordingly, there are values or commitments held by individuals that are irreducible to matters of incentive or deterrence. Indeed, their reduction purely to matters of individual incentive or disincentive precisely betrays such values or commitments.

As lampooned by Veblen $(1919,73)$, the utilitarian approach treats the individual as a "lightning calculator of pleasures and pains ... . a homogeneous globule of desire." In contrast, ethical commitments and moral habits introduce a new dimension that we ignore at our peril. John Maynard Keynes (1972, 445) saw utilitarianism and its overemphasis on the calculus of pleasure and pain "as the worm which has been gnawing the insides of modern civilization and is responsible for the present moral decay.” In a classic volume, Alasdair MacIntyre (1981) criticized the modern tendencies to regard moral values as entirely relative and subjective, to see the gratification of emotions as paramount, and to deem the definition of what is good as a purely private matter.

The emphasis on moral commitments implies that it is not simply the breach of a rule that is important in defining corruption. Consider legal rules in particular. Corruption is not always unlawful. Until 1977, it was legal for U.S. companies to offer bribes to secure foreign contracts, and in many countries, such inducements were lawful until 1997. More generally, rules can be broken by accident or through ignorance, and the breach of a rule does not necessarily constitute a corrupt act. Corruption "is not at bottom simply a matter of law; rather it is fundamentally a matter of morality" (Miller 2005).

Note the primary sense in which morality is being invoked here. In his early and influential paper, Nye (1967) attacked "moralistic" stances on corruption and warned against the "moralistic approach." This dismissal of morality is too sweeping. It is not foremost a question whether acts of corruption are themselves overall moral or immoral. As noted above, instances of "noble cause corruption" may on balance be morally justified, as in the case of Schindler's List. Instead, the leading issue concerning morality raised here is that all acts of corruption violate moral norms associated with rules, and despoil the moral character of the social role that is associated with the rule. When Schindler bribed the Nazi officials he violated moral as well as legal rules. However, the legitimacy of those rules was no more than that of the Nazi regime itself, and their moral violation was overshadowed by a much greater moral cause. The moral despoliation associated with rule violations exists even if the act of corruption may itself be morally justified overall, when all things are taken into account.

The key point here is that established and embedded social rules acquire a moral salience. We do not follow all rules simply because it is convenient to do so. To a greater or lesser degree, established rules have a normative dimension. This is true even of relatively arbitrary or idiosyncratic rules, such as the rules of language. People can take offense when English infinitives are split or an adult stranger in France is addressed as tu. People who break these rules 
will be told that they should be observed, whether or not it is convenient or preferred.

Utilitarians retort that the uncomfortable feelings caused by the displeasure of others when we break rules simply enter into the calculus of pleasure and pain, alongside the net utility we may gain directly from breaking the rule. Critics respond that this reduces the individual to a calculating machine, thereby dissolving irreducible aspects of individual personality such as dignity and self-regard. Exclusively instrumental utilitarian arguments undermine such important functional values as respect for the law. At the same time, contrary to much of its rhetoric, utilitarianism does not get rid of the question of morality and thereby attain "scientific" status. Instead, it reduces morality to narrower questions of individual pleasure or greed.

As Walter Schultz (2001) explains at length, moral constraints are necessary for markets to function. These moral conditions include social practices that enforce property rights, rights to true information, and rights to welfare and autonomy. Schultz insists that the market is a social institution, involving normative social practices. The market is not a morality-free zone. Joseph Schumpeter $(1976,423-4)$ famously wrote that "no social system can work which is based exclusively upon a network of free contracts between (legally) equal contracting parties and in which everyone is supposed to be guided by nothing except his own (short-run) utilitarian ends." The reinstatement of a non-utilitarian concept of morality is necessary to understand the phenomenon of corruption. Sadly, in part by embracing a crude utilitarianism, modern economics has corrupted the concept of corruption.

We are now in a position to sketch a definition of organizational corruption that acknowledges its ethical and rule-related character:

By definition, organizational corruption involves at least two agents, $X$ and $Y$, where at least $Y$ occupies at least one designated role that is attached to a particular organization. This organizational role obliges $Y$ to follow an established set of ethical rules, at least some of which are consistent with the goals of the organization. $X$ consciously intends an action, which is deliberately designed to cause or persuade $Y$ to breach at least one of these goal-consistent ethical rules, of which $X$ and $Y$ are both aware. With the option of acting otherwise, $Y$ violates this rule in accord with the wishes of $X$.

What is crucial is that organizational corruption undermines the capacity of the organization to fulfill its own objectives. Note also that moral conditions are vital to this definition. If a rule has no ethical content, then its breach is of no moral consequence and the violation can hardly be regarded as corrupt. Observe also that bribes or payments are strictly inessential to this definition, even if money often changes hands. Corruption can and does occur on the basis of camaraderie, expected reciprocity, family ties or whatever. Furthermore, dishonesty is also strictly inessential to this definition. Although corrupt agents typically lie to conceal their violations of the rules, there are circumstances where such breaches can be acknowledged and go unpunished.

If an act involves one person only, then it is not organizational corruption, which involves both collusion and the violation of organizational rules. If $Y$ acts alone to embezzle funds, then this is not organizational corruption because no collusion is involved, notwithstanding the breach of organizational and legal rules. It is unnecessary for our purposes here to define further other forms of corruption: in some general cases we may rely on the Latin-based etymological meaning, as cited above.

Also, there is no specification that $X$ and $Y$ are necessarily principal and agent (or agent and principal) as in some influential studies (Banfield 1975).

Corruption can occur when $X$ and $Y$ simply collaborate to break the organizational rules.

The criterion of goal-consistency is important for the following reason. Organizations often lay down particular rules that conflict with other overt goals, such as producing high-quality goods or maximizing shareholder value. For example, rules concerning secrecy may limit scrutiny and discussion. In such cases, $X$ acting to cause $Y$ to breach a secrecy rule would not necessarily be an act of corruption. Organizational corruption refers to the erosion of organizational capacities that are in accord with organizational purposes. Of course, what is and is not goal-consistent is often open to dispute. Consequently there may be a number of debatable cases concerning what is and what is not corruption. However, the fact that the true situation is complex and its investigation leads to disagreement, does not mean that that there no single truth to be discovered.

The above definition of organizational corruption is in general terms. However, because corruption is defined in relation to specific organizational roles and ethical rules, what is organizationally corrupt in one organizational, ethical and cultural context may not be organizationally corrupt in another. The definition is general, but the results may be historically or geographically specific. 
This raises the question of whether it is legitimate today to judge contemporary China or India (for example) by the roles, rules and ethical standards that are associated with Western countries? We believe that in some spheres, and primarily in business and international political relations, some common criteria of judgment are now legitimate. The reason is that the basic institutions of property, contract, trade and political treaty are now global in their reach, although nuanced by an enormous number of important variations and peculiarities in specific cultural and national contexts. One of the consequences of globalization is that basic standards concerning commerce and international diplomacy have also become global. To this extent, corruption can be appraised and measured in global terms.

Finally, how does the definition relate to disparities between declared legal or organizational rules, on the one hand, and prevailing and established practices, on the other? Consider a written ethical rule concerning an organizational role that is widely ignored by the people fitting this role. The ethical rule could be specific to the organization, or it could be a legal rule. For example, employees may routinely ignore a written rule of honesty in their claims for business expenses.

We must ask in specific cases if the widespread breaches of the ethical rule are sustained with or without the use of organizational corruption. Clearly, if such corruption is required to maintain its neglect, then corruption must be present. Obversely, if the widespread breaches are not impelled by organizational corruption, then organizational corruption is unnecessary in this case. The declared ethical rule may eventually lapse into obscurity and lose its purchase.

The above definition of organizational corruption does not apply to roles and ethical rules that are poorly established in habits and sentiments. Such corruption occurs when there is tension between (a) roles and rules that are established in the habits of thought and behavior of a significant group of people, and (b) other lingering or emerging habits that undermine those roles and rules. With organizational corruption, (a) refers to longstanding rules and practices in the organization, and (b) are often intrusions from elsewhere. Corruption is thus a dynamic process involving conflict between different sets of habits and norms.

\section{Social Costs of Organizational Corruption}

Some early studies of corruption, notably by Nathaniel Leff (1964) and Samuel Huntington (1968) uphold that the benefits of corruption can exceed the costs. Against the protestations of Gunnar Myrdal (1968) and others, it is said that bribery can reduce delays and provide incentives for officials (Lui 1985). Huntington (1968, 386) famously declared: "In terms of economic growth, the only thing worse than a society with a rigid, over-centralized, dishonest bureaucracy is one with a rigid, overcentralized, honest bureaucracy." Corruption is regarded as the champion of economic efficiency against the stultifying state bureaucracy. These arguments overlook the possibility that the state may be necessary to sustain commerce and enforce contracts. Corruption undermines such powers: the outcome may be that it is more difficult to implement contracts, to the detriment of business activity and output. ${ }^{16}$

The utilitarian arguments employed by Leff and Huntington echo Bernard Mandeville in his Fable of the Bees: where private vices lead to public virtues. These arguments imply, for example, that the voluntary acceptance of bribes to vote for a person in a democratic election increase the welfare of the briber as well as the bribed. The problem is that the values and institutions of democracy are also corrupted by such actions (Seligsson 2002).

In a more balanced mainstream approach, Acemoglu and Verdier (2000) establish a trade-off between, on the one hand, the benefits of diminishing (public) corruption by reducing state intervention and, on the other hand, the need to retain some state intervention to deal with market failures. Both the benefits and disbenefits of state intervention in the economy are acknowledged. However, this analysis not only ignores corruption in the private sphere but also the negative externalities of corruption in any context.

The key question here is whether corruption can have social costs. Organizational corruption in particular undermines the capacity of the organization to act, and to use or dispose of its property, in accord with the legitimate aims and objectives of its owners or managers. Is corruption an example of an activity that may have benefits for the individuals involved, but has negative externalities that impose social costs on the community as a whole, by undermining the institutional fabric of commercial activity?

Such affirmations face the problem that the very concept of social costs has become less fashionable since the influential critique of Ronald Coase (1960). For example, if it were possible to specify individual property rights in one's environment, then polluters could be sued: the externalities would become internalized and the social cost of pollution would be transformed into private costs for individuals. 
Nevertheless, this Coasean solution depends on the full specification of individual property rights and the absence of 17

transaction costs.

Leaving aside many of the conceptual and practical problems involved with this topic and its huge literature, it must be noted that corruption has particular features that place additional difficulties in the way of a Coasean argument. Essentially, is it possible to establish property rights in the institutional fabric through which contracts and property rights are themselves sustained? There are special reasons here for answering in the negative. Enforceable and well-defined property rights cannot be an effective solution to the social problem of corruption, when corruption disrupts the whole institutional system of private property and contract. Within the Coasean argument, corruption establishes a self-referential tangle where the property rights solution is undermined by corruption itself. Corruption creates transaction costs and uncertainties that are absent from the Coasean model. Corruption is thus the nemesis of the Coasean solution.

As far as I am aware, Coase himself has not suggested that the particular externalities involved in corruption can be internalized. Indeed, Coase's testimony can be used to support the contrary stance. He has repeatedly drawn attention to the importance of the institutional structures of economic activity. For example, Coase $(1988,10)$ insists that "markets require . . the establishment of legal rules governing the rights and duties of those carrying out transactions." As if he were following original institutionalist maxims (Commons 1924; Samuels 1989), Coase further argues that these legal rules cannot always emerge privately: they require the sustenance of the state:

Such legal rules may be made by those who organize the markets, as is the case with most commodity exchanges. The main problems faced by the exchanges in this law making are the securing of the agreement of the members of the exchange and the enforcement of its rules ... When the physical facilities are scattered and owned by a vast number of people with very different interests ... the establishment and administration of a private legal system would be very difficult. Those operating in these markets have to depend, therefore, on the legal system of the State. (1988, 10)

Not only is it impossible to dismiss the social costs of corruption by using a Coasean argument, but also, Coase himself insists that a properly functioning state legal system is necessary to sustain property rights, upon which a Coasean argument depends. Although Coase does not mention corruption in this context, it would be consistent with his stance to uphold that when corruption undermines institutional rules that help to sustain economic activity then it must be regarded as a negative externality or positive social cost.

Corruption is an important area where social costs must be considered, and they cannot be dissolved within a universal Coasean framework of property rights allocation. Nevertheless, this does not mean that property rights are unimportant.

While the costs of corruption cannot be entirely internalized by a better assignment of property rights, the minimization of corruption will depend on institutional design, involving matters of incentives and property rights assignment.

\section{Conclusion}

The central argument in this paper is that the concept of corruption itself has been corrupted by the utilitarian underpinnings of mainstream economics and the ideological prejudices of many mainstream economists against state activity. The commonplace definition of corruption as the abuse of public office for private gain, itself reflects this conceptual corruption. Most importantly, there is no good reason why organizational corruption should be definitionally confined to the public sector, especially given the corporate scandals experienced in modern corporations. Furthermore, in exceptional cases, organizational corruption can be motivated other than by private gain.

An alternative approach, drawing from the institutionalist literature, highlights two issues that are missing from the commonplace definition of corruption. First is the ontological claim that rules are key elements of social being; institutions - defined as systems of established and ingrained social rules - are the stuff of social life. Second, established social rules have to some degree a normative character. Organizational corruption by definition involves the breach and moral violation of these rules, with the effect of undermining their future efficacy.

Insofar as these rules contribute to human needs and social welfare, their erosion by organizational 
corruption means negative externalities and positive social costs, despite the fact that the individuals directly involved may gain from the corrupt act. These externalities and social costs cannot fully be internalized by defining property rights, because they erode the institutional fabric of private property rights upon which any internalization depends.

Corruption reduces levels of trust in dealing with both business and the state. Consequently, corruption encourages the reliance upon ethnic, religious, family and other ties, where contract enforcement relies on sanctions and reputational effects within a defined group (Landa 1994). Business life becomes fractured into clans or illegal mafias, with the loss of the benefits of wider cooperation and competition. The efficacy of the general, inclusive and non-discriminatory legal rules that are necessary for the operation of a modern, complex, market economy is undermined (Hayek 1960; Weingast 2005; Hodgson 2006b).

Leading authorities such as the World Bank recognize that corruption is a growing global problem. Further empirical research and policy development to help arrest and reverse its spread around the world, should be based on a more careful definition of its nature and a more adequate understanding of the damage that it can inflict upon economic activity.

\section{Notes}

1. 1. www.transparency.org/cpi/2005/cpi2005_infocus.html (accessed May 31, 2007).

2. 2. web.worldbank.org/WBSITE/EXTERNAL/TOPICS/EXTPUBLICSECTORANDGOVERNANCE/

EXTANTICORRUPTION/.0,menuPK:384461 pagePK:149018 piPK:149093 theSitePK:384455, 00.html (accessed June 1, 2006).

3. 3. Bukovansky (2006) discusses the nature and context of the growing anti-corruption discourse.

4. 4. www.unodc.org/unodc/en/corruption.html (accessed May 31, 2007).

5. 5. www.transparency.org/news_room/faq/corruption_faq (accessed May 31, 2007).

6. 6. For another overview of recent literature in economics on corruption, see Hopkins (2002).

7. 7. Lambsdorff et al. (2004) provide a set of essays on the "new institutional economics" of corruption. Much of the analysis in these essays differs from the one undertaken here, but commendably several of the authors stress private, as well as public sector corruption. Among other exceptions, Bardhan (1997) and Svensson (2005) point out that corruption takes place in the private as well as the public sector. To his credit, Adam Smith (1776) also acknowledged the problem of private sector corruption, although he used different words such as "malversation" and "embezzling" to describe such phenomena. Regrettably, the focus of concern today among economists seems to be different.

8. $8 . \quad$ There is a significant literature on corporate fraud and corruption, including major studies such as Clinard (1990). Nevertheless, academic journals in the social sciences remain biased towards corruption in the public sphere.

9. 9. There are several models of corruption, treating it either as a contagion process, or as a persistent outcome in models with multiple equilibria (Andvig and Moene 1990; Mishra 2006; Sah 1991; Tirole 1996). See Cartier-Bresson (1997) on "corruption networks."

10. 10. See, for example, Root (1996), White (1996), Kaufmann (1997), Manion, (1996) and He (2000). Christopher Bliss and Rafael Di Tella (1997) devise a model that shows that increases in competition may not lower corruption.

11. 11. This point is recognized not only by the original institutionalists but also by "new" institutionalists such as Sened (1997) and Mantzavinos (2001).

12. 12 In Hodgson (2006a), I show that contrary to a widespread but mistaken interpretation, Douglass North also regards organizations as a type of institution.

13. 13. These dissenters include Thomas Robert Malthus, John Ruskin, Charles Sanders Peirce, Gustav Schmoller, John Maynard Keynes, Joseph Schumpeter, Amartya Sen, and leading institutional economists such as John A. Hobson, Karl Polanyi and K. William Kapp. For an historical overview see Lutz (1999), and for a modern statement see Etzioni (1988).

14. 14. The definition of "institutional corruption" in Miller (2005) and Miller, Roberts and Spence (2005) inspired the formulation that follows, albeit with significant modifications. Their definition depends on the existence of institutional purposes and roles, which in fact are confined to organizations. Following terminology established elsewhere, organizations are a special kind of institution involving membership, rules and roles. Examples of organizations include states, political parties, business corporations, trade unions and private societies (Hodgson 2006 a).

"Institution" is a broader term, covering additional phenomena such as language (Searle 1995). Hence, the term "organizational corruption" is preferred here.

15. 15 . Andvig (2006) treats corruption as the intrusion of norms in family and other social contexts into political and bureaucratic

fields.
16. $16 . \quad$ Positive views of corruption as greasing the wheels of economic activity are criticized by Leys (1965), Bardhan (1997),

Kaufmann (1997), Shleifer and Vishny (1993) and several others.

17. 17. Important differences between Coase's own position and the ideas of some of his "Coasean" followers will not be elaborated upon here. These differences have been widely discussed, in for example Medema (1994).

\section{References}

Acemoglu, Daron, and Thierry Verdier. "The Choice between Market Failures and Corruption." American Economic Review 90, 1 (March 2000): 194-211.

Andvig, Jens Christian. "Corruption and Fast Change." World Development 34, 2 (February 2006): 328-340.

Andvig, Jens Christian, and Karl Ove Moene. "How Corruption May Corrupt." Journal of Economic Behavior and Organization 13, 1 (January 1990): 63-76.

Aidt, Toke S. ”Economic Analysis of Corruption: A Survey." Economic Journal 113, 8 (November 2003): F632-F652. 
Banfield, Edward C. "Corruption as a Feature of Governmental Organization." Journal of Law and Economics 18, 3 (1975): 587-605.

Bardhan, Pranab K. "Corruption and Development: A Review of the Issues.” Journal of Economic Literature 35, 3 (September 1997): $1320-1346$.

Bliss, Christopher, and Rafael Di Tella. "Does Competition Kill Corruption?" Journal of Political Economy 105, 5 (October 1997): 1001-1023.

Bukovansky, Mlada. "The Hollowness of Anti-Corruption Discourse." Review of International Political Economy 13, 2 (May 2006): 181-209.

Cartier-Bresson, Jean. "Corruption Networks, Transaction Security and Illegal Social Exchange." Political Studies 45, 3 (1997): 463-476.

Chang, Ha-Joon. "Breaking the Mould: An Institutionalist Political Economy Alternative to the Neo-Liberal Theory of the Market and the State." Cambridge Journal of Economics 26, 5 (September 2002): 539-559.

Clinard, Marshall B. Corporate Corruption: The Abuse of Power. New York and London: Praeger, 1990.

Coase, Ronald H. "The Problem of Social Cost." Journal of Law and Economics 3, 1 (October 1960): 1-44.

—. The Firm, the Market, and the Law. Chicago: University of Chicago Press, 1988.

Commons, John R. Legal Foundations of Capitalism. New York: Macmillan, 1924.

Crawford, Sue E. S., and Elinor Ostrom. "A Grammar of Institutions." American Political Science Review 89, 3 (September 1995): 582-600.

Dopfer, Kurt, John Foster, and Jason Potts. "Micro-Meso-Macro." Journal of Evolutionary Economics 14, 3 (July 2004): 263-279.

Etzioni, Amitai. The Moral Dimension: Toward a New Economics. New York: Free Press, 1988.

Fligstein, Neil. The Architecture of Markets: An Economic Sociology of Twenty-First Century Capitalist Societies. Princeton, NJ: Princeton University Press, 2001.

Friedman, Allen, and Ted Schwarz. Power and Greed: Inside the Teamsters Empire of Corruption. New York: Franklin Watts, 1989.

Gardiner, John A. "Defining Corruption." Corruption and Reform 7, 2 (1993): 111-124.

Hagstrom, Warren O. The Scientific Community. New York: Basic Books, 1965.

Hayek, Friedrich A. The Constitution of Liberty. London and Chicago: Routledge and Kegan Paul, and University of Chicago Press, 1960.

He, Zengke. "Corruption and Anti-Corruption in Reform China." Communist and Post-Communist Studies 33 (2000): 243-270.

Hodgson, Geoffrey M. Economics and Institutions: A Manifesto for a Modern Institutional Economics. Cambridge and Philadelphia: Polity Press and University of Pennsylvania Press, 1988.

—. "The Ubiquity of Habits and Rules." Cambridge Journal of Economics 21, 6 (November 1997): 663-684.

—. "The Enforcement of Contracts and Property Rights: Constitutive versus Epiphenomenal Conceptions of Law." International Review of Sociology 13, 2 (July 2003): 373-389.

—. "What Are Institutions?" Journal of Economic Issues 40, 1 (March 2006a): 1-25.

_. "Institutions, Recessions and Recovery in the Transitional Economies." Journal of Economic Issues 40, 4 (December 2006b): 875-894.

Hodgson, Geoffrey M., and Thorbjørn Knudsen. "The Complex Evolution of a Simple Traffic Convention: The Functions and Implications of Habit." Journal of Economic Behavior and Organization 54, 1 (September 2004): 19-47.

Hopkins, Jonathan. "States, Markets and Corruption: A Review of some Recent Literature." Review of International Political Economy 9, 3 (August 2002): 574-590.

Huntington, Samuel P. Political Order in Changing Societies. New Haven, CT: Yale University Press, 1968.

Jain, Arvind K. "Corruption: A Review." Journal of Economic Surveys 15, 1 (February 2001): 71-120.

Kaufmann, Daniel. "Corruption: The Facts.” Foreign Policy 107, 1 (Summer 1997): 114-131.

Keynes, John Maynard. The Collected Writings of John Maynard Keynes, Vol. X, Essays in Biography. London: Macmillan, 1972.

Kilpinen, Erkki. The Enormous Fly-Wheel of Society: Pragmatism's Habitual Conception of Action and Social Theory. Helsinki: University of Helsinki, 2000.

Lambsdorff, Johann Graf, Markus Taube, and Matthias Schramm (eds.). The New Institutional Economics of Corruption. London and New York: Routledge, 2004.

Landa, Janet. Trust, Ethnicity, and Identity: Beyond the New Institutional Economics of Ethnic Trading Networks, Contract Law, and Gift Exchange. Ann Arbor, MI: University of Michigan Press, 1994.

Leff, Nathaniel. "Economic Development Through Bureaucratic Corruption.” American Behavioral Scientist (1964): 8-14.

Levin, Mark, and Georgy Satarov. "Corruption and Institutions in Russia." European Journal of Political Economy 16, 1 (March 2000): 113-132.

Leys, Colin. "What is the Problem About Corruption?" Journal of Modern African Studies 3, 2 (1965): 215230.

Lowry, S. Todd. "Bargain and Contract Theory in Law and Economics." Journal of Economic Issues 10, 1 (March 1976): 1-22.

Lui, Francis T. “An Equilibrium Queuing Model of Bribery." Journal of Political Economy 93, 4 (August 1985): 760-781.

Lutz, Mark A. Economics for the Common Good: Two Centuries of Social Economic Thought in the Humanistic Tradition. London and New York: Routledge, 1999.

MacIntyre, Alasdair. After Virtue: A Study in Moral Theory. London: Duckworth, 1981.

Manion, Melanie. "Corruption by Design: Bribery in Chinese Enterprise Licensing." Journal of Law, Economics, and Organization 12, 1 (April 1996): 167-195.

Mantzavinos, Chris. Individuals, Institutions and Markets. Cambridge and New York: Cambridge University Press, 2001.

Mauro, Paolo. “Corruption and Economic Growth.” Quarterly Journal of Economics 110, 3 (August 1995): 681-712.

McMillan, John. Reinventing the Bazaar: A Natural History of Markets. New York and London: Norton, 2002.

Medema, Steven G. Ronald H. Coase. Basingstoke and New York: Macmillan and St Martin's Press, 1994.

Miller, Seumas. "Corruption." The Stanford Encyclopedia of Philosophy (Fall 2005 Edition), Edward N. Zalta (ed.), http://plato.stanford.edu/archives/fall2005/entries/corruption/ (accessed May 31, 2007).

Miller, Seumas, Peter Roberts, and Edward Spence. Corruption and Anti-Corruption: An Applied Philosophical Approach. Englewood Cliffs, NJ: Prentice Hall, 2005.

Mishra, Ajit. "The Persistence of Corruption: Some Theoretical Perspectives.” World Development 34, 2 (February 2006): 349-358.

Myrdal, Gunnar. Asian Drama: An Inquiry into the Poverty of Nations. Harmondsworth and New York: Penguin and Twentieth Century Fund, 1968.

Nye, Joseph S. "Corruption and Political Development: A Cost-benefit Analysis." American Political Science Review 61, 2 (June 1967): 417-427.

Ouellette, Judith A., and Wendy Wood. "Habit and Intention in Everyday Life: The Multiple Processes by which Past Behavior Predicts Future 
Behavior." Psychological Bulletin 124 (1998): 54-74.

Ostrom, Elinor. "An Agenda for the Study of Institutions." Public Choice 48 (1986): 3-25.

Peirce, Charles Sanders. "How to Make Our Ideas Clear." Popular Science Monthly 12 (January 1878): 286302.

Pellegrini, Lorenzo. and Reyer Gerlagh. "Corruption's Effect on Growth and its Transmission Channels.” Kyklos 57, 3 (2004): 429-456.

Polinsky, A. Mitchell, and Steven Shavell. "Corruption and Optimal Law Enforcement." Journal of Public Economics 81, 1 (July 2001): 1-24.

Potts, Jason. The New Evolutionary Microeconomics: Complexity, Competence and Adaptive Behaviour. Cheltenham: Edward Elgar, 2000.

Root, Hilton. "Corruption in China: Has It Become Systemic?" Asian Survey 36, 8 (August 1996): 741-757.

Rose-Ackerman, Susan. Corruption and Government: Causes, Consequences and Reform. Cambridge and New

York: Cambridge University Press, 1999. Sah, Raaj. "Social Osmosis and Patterns of Crime.” Journal of Political Economy 99, 6 (1991):

1272-1295.

Samuels, Warren J. “The Legal-Economic Nexus.” George Washington Law Review 57, 6 (August 1989): 15561578.

Sandholtz, Wayne, and William Koetzle. "Accounting for Corruption: Economic Structure, Democracy, and Trade." International Studies Quarterly 44 (2000): 31-50.

Schultz, Walter J. The Moral Conditions of Economic Efficiency. Cambridge and New York: Cambridge University Press, 2001.

Schumpeter, Joseph A. Capitalism, Socialism and Democracy, 5th ed. London: George Allen and Unwin, 1976.

Searle, John R. The Construction of Social Reality. London: Allen Lane, 1995.

Seligson, Mitchell A. "The Impact of Corruption on Regime Legitimacy." Journal of Politics 64, 2 (2002): 408-433.

Sened, Itai. The Political Institution of Private Property. Cambridge: Cambridge University Press, 1997.

Shleifer, Andrei, and Robert W. Vishny. "Corruption." Quarterly Journal of Economics 108, 3 (August 1993): 599-617.

Smith, Adam. An Inquiry into the Nature and Causes of the Wealth of Nations, 2 vols. London: Strahan and Cadell, 1776.

Svensson, Jakob. "Eight Questions about Corruption." Journal of Economic Perspectives 19, 3 (Summer 2005): 19-42.

Tanzi, Vito. Politics, Institutions and the Dark Side of Economics. Cheltenham: Edward Elgar, 2000.

Tirole, Jean. "A Theory of Collective Reputations." Review of Economic Studies 63, 1 (1996): 1-22.

Treisman, Daniel. “The Causes of Corruption: A Cross-National Study.” Journal of Public Economics 76, 3 (June 2000): 399-457.

Vanberg, Viktor J. "Rational Choice versus Program-Based Behavior: Alternative Theoretical Approaches and Their Relevance for the Study of Institutions." Rationality and Society 14, 1 (Summer 2002): 7-53.

Veblen, Thorstein B. The Place of Science in Modern Civilization and Other Essays. New York: Huebsch, 1919.

Warren, Mark E. "What Does Corruption Mean in a Democracy?" American Journal of Political Science 48, 2 (April 2004): 328-343.

Weingast, Barry R. "The Constitutional Dilemma of Economic Liberty.” Journal of Economic Perspectives 19, 3 (Summer 2005): 89-108.

White, Gordon. "Corruption and the Transition from Socialism in China." Journal of Law and Society 23, 1 (March 1996): 149-169.

Wood, Wendy, Jeffrey M. Quinn, and D. Kashy. "Habits in Everyday Life: Thought, Emotion, and Action." Journal of Personality and Social Psychology 83 (2002): 1281-1297.

World Bank. Helping Countries Combat Corruption: The Role of the World Bank. Washington DC: World Bank, 1997. 